\title{
Reactions towards Asylum Seekers in the Netherlands: Associations with Right-wing Ideological Attitudes, Threat and Perceptions of Asylum Seekers as Legitimate and Economic
}

\author{
EMMA ONRAET
}

Department of Developmental, Personality, and Social Psychology, Ghent University, Gent 9000, Belgium

ALAIN VAN HIEL

Department of Developmental, Personality, and Social Psychology, Ghent University, Gent 9000, Belgium

BARBARA VALCKE

Department of Developmental, Personality, and Social Psychology, Ghent University, Gent 9000, Belgium

JASPER VAN ASSCHE

Department of Developmental, Personality, and Social Psychology, Ghent University, Gent 9000, Belgium

MS received March 2019; revised MS received October 2019

The present study conducted in the Netherlands examines citizen's attitudes towards asylum seekers. We collected data in a large $(N=993)$ heterogeneous adult sample in November 2015, in the midst of the European "refugee crisis". Our first aim was to map the reactions of citizens towards asylum seekers. Our second aim was to examine the role of right-wing ideological attitudes (i.e., Right-Wing Authoritarianism and Social Dominance Orientation) in explaining these reactions. With respect to the first research aim, it was revealed that, on average, our respondents were rather unwilling to help asylum seekers. Moreover, respondents were more welcoming towards legitimate asylum seekers (who are on the run from war and violence in their home country) compared to economic asylum seekers. With respect to the second research aim, we found that right-wing attitudes were related to stronger negative reactions towards asylum seekers. Moreover, individuals higher on right-wing ideological attitudes were more likely to perceive asylum seekers as being economic asylum seekers and less as legitimate asylum seekers, which related to stronger feelings of threat and ultimately, to more negative reactions towards asylum seekers. 
Keywords: authoritarianism, economic asylum seeker, Netherlands, prejudice, social dominance orientation, threat

Since 2015, the world has been confronted with a rise in the prevalence of asylum seekers. According to the Global Trends in Forced Displacement report of the UN Refugee Agency, in 2015, over 65 million individuals worldwide were displaced from their homes - the highest number in recorded history (United Nations High Commissioner for Refugees (UNHCR) 2015; Edwards 2016). Over recent years, Europe has been confronted with the largest refugee influx since the Second World War. In 2015, Statistics Netherlands counted more than 58,000 applications for asylum, which is more than the double compared to the year before. ${ }^{1}$ This influx of asylum seekers is often referred to as the 'refugee crisis' and has resulted in social tensions and fierce public debates among the citizens of receiving countries. Reactions to these raising figures were very diverse. A part of the population emphasized the need for empathy, claiming that it is a moral duty to receive asylum seekers and to do everything to make them feel welcome and to help them. Other members of the public reacted strongly negatively and unwelcoming, leading to, for example, protest against new centres receiving asylum seekers (see Georgiou and Zaborowski 2017; Koc and Anderson 2018).

Verkuyten (2018) argued that increasing migration and diversity raise new interesting topics for the field of social psychology. Among other potential research lines, he stressed the need for research concerning the question of 'how to get along' and how host societies respond to immigration and increasing cultural diversity. He also emphasized the need to investigate prosocial behaviour towards newcomers. Our study aligns with this call. More specifically, we focus on reactions of Dutch citizens towards asylum seekers. We collected data in a large heterogeneous community sample in the middle of the 'refugee crisis' in 2015, when asylum seekers were a 'hot' topic in the media and in the public debate. The aims of our study were multiple. First, we wanted to map the reactions to asylum seekers in the Netherlands. In other words, how (un)welcoming are Dutch citizens towards asylum seekers? We hereby focus on displayed helping behaviour, support for policies concerning asylum seekers and welcoming attitudes towards asylum seekers. This first research aim was mainly exploratory, as we had no specific theory-based hypothesis. However, we expected the average reactions to be slightly more on the negative side based on public-opinion polls around the time of our data collection. These polls showed that the overall attitudes and perceptions of asylum seekers by inhabitants of many Western countries tend to more negative than positive (IPSOS 2016; PEW Research Center 2016).

Our second aim was to examine how right-wing ideological attitudes (i.e. Right-Wing Authoritarianism (RWA) and Social Dominance Orientation (SDO)) influence these reactions towards asylum seekers. This specific aim can be addressed in a theoretically guided way, as previous studies have amply shown strong relationships between the right-wing attitudes on the 
one hand and a harsh orientation towards ethnic minorities and out-groups on the other (e.g. Altemeyer 1998; Thomsen et al. 2008; Golec de Zavala et al. 2010). Furthermore, RWA and SDO have also been related to a negative sentiment towards asylum seekers in particular (see Anderson and Ferguson 2018; Cowling et al. 2019). Besides investigating this main relationship, we also aimed to uncover the underlying processes by examining the perception of asylum seekers as legitimate or as economic (e.g. Bansak et al. 2016) and experienced threat (e.g. Schweitzer et al. 2005; Riek et al. 2006) as possible mediators. Especially the role of the perception of asylum seekers as a process variable is interesting in the present context. The distinction between legitimate and economic asylum seekers has often been made in the media and in political communication (Verkuyten 2004) but, to the best of our knowledge, it has not been studied yet as a relevant process variable in between right-wing attitudes and (un)welcoming attitudes.

\section{The Relationship between Right-wing Ideological Attitudes and Reactions towards Asylum Seekers}

A comprehensive view on right-wing attitudes requires the differentiation between two dimensions: one pertaining to the social-cultural domain and the other one referring to the economic-hierarchical domain (e.g. Eysenck 1954; Middendorp 1978; Lipset 1981; Altemeyer 1998; Duckitt and Sibley 2009). Right-wing social-cultural attitudes refer to adherence to traditional values and norms and resistance to change. RWA (Altemeyer 1981, 1998) is a typical indicator of such attitudes and pertains to uncritically submitting to authorities, adhering to traditional norms and values of the society, and showing aggressiveness towards others who deviate from these conventional norms and values. Economic-hierarchical right-wing attitudes emphasize hierarchy and inequality between groups in the distribution of power, income and opportunities. SDO (Pratto et al. 1994) is a typical indicator of the economichierarchical domain and is defined as a preference for hierarchically structured group relations and inequality among social groups. In the literature, there is a strong empirical and theoretical basis for the claim that individuals higher on RWA and SDO are more likely to exhibit negative attitudes towards different out-groups, including immigrants (Sidanius and Pratto 1999; Duckitt 2001; Sibley and Duckitt 2008; Kteily et al. 2012).

RWA and SDO have also been put forward as important correlates of attitudes and reactions towards asylum seekers as well. Scholars have shown that individuals with higher levels of RWA and SDO are more likely to have negative attitudes or to react negatively towards asylum seekers (for metaanalyses, see Anderson and Ferguson 2018; Cowling et al. 2019). Specifically, both RWA and SDO uniquely contribute to the explained variance in these negative reactions (Lyall and Thorsteinsson 2007; Anderson et al. 2015; Anderson 2018a, 2018b; Mancini et al. in press). Moreover, these 


\section{Emma Onraet et al.}

attitudes relate not only to negative sentiments with respect to asylum seekers, but also to less positive (i.e. prosocial) opinions and behaviours vis-à-vis this particular group. Mancini et al. (in press) reported that RWA and SDO were negatively related to the extent to which participants would engage in prosocial behaviours such as donating money to a charity that benefits asylum seekers.

\section{The Perception of Asylum Seekers as Legitimate and Economic as Process Variables}

In the media as well as in the public debate, a distinction has often been made between legitimate versus economic asylum seekers. The first type refers to individuals who flee their country and seek asylum elsewhere because they are faced with war, violence or imminent danger in their home country. The second type refers to individuals who are not necessarily forced to leave their country because of danger, but instead seek asylum because they wish to build a better (economic) future for themselves and their family. Bansak et al. (2016) showed that Europeans are more willing to accept legitimate asylum seekers than those asking for asylum because of economic reasons. Although it is impossible to numerically capture the proportion of legitimate and economic asylum seekers, people often have their own perceptions of the motivation of asylum seekers and these perceptions may affect their emotional responses and reactions. Verkuyten (2004) found that legitimate asylum seekers elicit feelings of sympathy, whereas economic asylum seekers are perceived responsible for their situation and undeserving of help, even fuelling feelings of anger, and that these emotions shape the individual's support for policies concerning immigrants. Hercowitz et al. (2017) reported that the perception of asylum seekers as non-genuine leads to exclusionary attitudes towards asylum seekers because they are perceived as more threatening.

In the present study, we take this distinction between legitimate and economic asylum seekers into account to explain the relationship between right-wing attitudes and reactions towards asylum seekers. In politics, a sharp distinction between legitimate and economic asylum seekers is often made. Especially right-wing politicians frame asylum seekers as 'economic migrants', 'fortune seekers', 'so-called refugees' and 'infiltrators' who are a threat to the society and take advantage of a country's hospitality. Such framing effects of immigration can have consequences on how people perceive asylum seekers, and consequently may have an impact on their attitudes toward asylum seekers (Anderson and Antalíková 2014). We expect that citizens with right-wing attitudes adopt a similar rhetoric in their own reactions towards asylum seekers.

\section{The Role of Threat as a Process Variable}

Threat has already been considered as an underlying process variable that explains the effects of ideological attitudes on negative out-group attitudes in general, and attitudes towards asylum seekers specifically (Schweitzer et al. 2005; Louis et al. 2007). In the meta-analysis of Cowling et al. (2019), threat was even reported to yield the highest effect size on prejudice against refugees of 
all included variables, although it should be acknowledged that only data of three samples were available. Members of out-groups in general, and asylum seekers in particular, can be perceived as a source of competition for tangible outcomes such as jobs, money and housing ('realistic threats'), but also as a source of threat to more abstract features of the in-group, such as its norms and values, religion, identity and so on ('symbolic threats'; Stephan and Stephan 2000; Esses et al. 2017). Individuals high in RWA and SDO are generally more threat-sensitive compared to those scoring low on these variables (Onraet et al. 2013) and the experience of out-group threats is considered to be a strong predictor of negative out-group attitudes (Riek et al. 2006), also in the case of asylum seekers (Schweitzer et al. 2005; Cowling et al. 2019). Several authors (e.g. Louis et al. 2007; Canetti et al. 2016) have shown that high scores on RWA and SDO coincide with an increased tendency to perceive asylum seekers as posing a threat to society and, as a result, more negative reactions towards these asylum seekers such as in the form of support for exclusionary asylum policies. In the present study, we further elaborate on these findings and investigate whether the perception of asylum seekers as legitimate and economic serves as an additional explanatory mechanism in these relationships.

\section{The Present Study}

The present study has two aims. First, we want to map the reactions of Dutch citizens towards asylum seekers in the middle of the European 'refugee crisis'. In other words, we wanted to answer the question of whether the Netherlands is a rather welcoming or unwelcoming society for asylum seekers. For this purpose, we collected a heterogeneous sample of Dutch inhabitants and investigated differences between demographic groups in terms of age, gender, and educational and income level. We also discerned between (self-reported) behavioural reactions (i.e. the extent to which Dutch inhabitants show helping behaviour towards asylum seekers), support for policies (i.e. support for lenient versus harsh policies concerning asylum seekers) and welcoming attitudes (i.e. attitudes towards 'legitimate' and 'economic' asylum seekers).

Our second aim was to examine the role of right-wing ideological attitudes in explaining these reactions towards asylum seekers. For this purpose, we administered the frequently used indicators of social-cultural right-wing (i.e. RWA) and economic-hierarchical right-wing (i.e. SDO) attitudes. Although RWA and SDO have been related to attitudes towards asylum seekers (see Anderson and Ferguson 2018; Cowling et al. 2019), most of this research has been conducted in Australia. Importantly, in the present study, we also investigated the role of participants' perceptions of asylum seekers as legitimate and as economic as well as experienced threat as possible mediators.

We thus formulated the following Hypothesis:

Right-wing attitudes relate directly and indirectly - through the serial mediation of both (i) the perceptions of asylum seekers as driven by legitimate and 
economic reasons and (ii) threat perception-with prosocial and exclusionary attitudes and behaviours towards asylum seekers.

\section{Method}

\section{Participants}

The data was collected online in November 2015 by an independent ISO 20252and ISO 26362-certified survey company, among inhabitants of the Netherlands without a migration background. ${ }^{2} \mathrm{~A}$ total of 993 individuals completed the questionnaire $(1,650$ people were originally contacted: response rate of 60 per cent). The mean age of the sample was 50.32 years $(\mathrm{SD}=16.70)$ ranging from 18 to 91 years; 52 per cent were male, 48 per cent female. Educational level was distributed as follows: 2.2 per cent of the participants had no formal education or had only completed primary school, 70.2 per cent had completed high school (30.7 of whom followed professional education and 39.5 per cent followed general education) and 27.6 per cent had obtained a degree in higher education (10.6 per cent of whom obtained a university degree). In terms of monthly gross household-income level, 9.5 per cent earned less than 12,500 euro, 17.4 per cent earned between 12,500 and 26,000 euro, 32.1 per cent earned between 26,000 and 39,000 euro, 27.9 per cent between 39, and 65,000 euro, and 13.1 per cent earned more than 65,000 euro.

\section{Measures}

All measures were rated on a seven-point Likert scale $(1=$ strongly disagree; $7=$ strongly agree), unless stated otherwise.

Helping behaviour We asked participants 'Did you do anything to help the asylum seekers?' together with the options 'yes' (9.8 per cent), 'not yet, but I want to' (24.2 per cent) and 'no, and I don't intend to' (66.1 per cent). Participants who had chosen one of the first two options were given a few follow-up questions asking 'What would you be willing to do, or did you already do, to help?' (answered $1=$ yes; $0=$ no) followed by a list consisting of 'signing a petition' (40.7 per cent), 'participating in a march' ( 4.7 per cent), 'financial gift to a helping organization' (44.2 per cent), 'collecting money' (11.9 per cent), 'donating food and clothes' (69.7 per cent), 'being a volunteer in a helping organization' (32.6 per cent), 'being a mentor for an under-aged asylum seeker' (26.1 per cent), 'welcoming an asylum seeker into my home' ( 4.2 per cent) and 'other' ( 8.3 per cent). For further analyses, we calculated a sum score of the various helping behaviours (participants choosing 'no, and I don't intend to' on the first helping measure received a score of 0$)(\alpha=0.72, M=0.82, S D=1.40)$.

Evaluation of policies regarding asylum seekers We asked participants' opinions on five Hypotheses regarding asylum seekers (rated on a seven-point 
Likert scale, 1 = definitely not, 7 = definitely yes): (1) 'The Netherlands should apply pressure on the European Union to close the external borders' $(M=4.64, S D=1.87)$, (2) 'The Netherlands should take care of all asylum seekers arriving in our country by giving them food, a place to sleep, and access to sanitary fittings until a decision on their application for asylum is made' $(M=5.04, S D=1.61)$, (3) 'The Netherlands should apply pressure on the European Union to make all asylum seekers apply for asylum in the first EU country they arrive in' $(M=4.87, S D=1.64)$, (4) 'The Netherlands should give asylum to families, but single men should be send back to their home country' $(M=3.61, S D=1.85)$ and (5) 'The Netherlands should give people who are granted asylum full access to social security' $(M=4.39$, $S D=1.80$ ). For further analyses, we calculated one indicator for 'support for harsh policies' based on the mean of these five items (reverse coding Hypotheses (2) and (5)) $(\alpha=0.71, M=3.94(S D=1.19)$.

Welcoming attitudes towards legitimate asylum seekers We presented the participants with the following three statements: 'I think that we should welcome asylum seekers on the run for war and violence', 'I think we should not accept many asylum seekers on the run for war and violence' (reversed item) and 'It is our moral duty to help asylum seekers on the run for war and violence'. For further analyses, we used the mean score of these three items $(\alpha=0.74, M=4.83, S D=1.27)$. Frequency analyses of the scale scores showed that the distribution is quite normal (with a small peak at the extreme welcoming end of the scale).

Welcoming attitudes towards economic asylum seekers We presented the participants with the same questions as above, but with 'economic asylum seekers' instead of 'asylum seekers on the run for war and violence'. For further analyses, we calculated the mean score of these three items $(\alpha=0.75$, $M=2.70, S D=1.34)$. A large group of respondents is very unwelcoming towards economic asylum seekers (with more than 20 per cent of respondents scoring at the extreme unwelcoming end of the scale). Only 12 per cent of respondents score above the midpoint of the scale and can thus be considered to be welcoming towards economic asylum seekers.

Right-wing authoritarianism ( $R W A$ ) A six-item RWA scale (based on Altemeyer 1981; see Onraet et al. 2014) was administered. A sample item is 'Obedience and respect for authority are the most important virtues children should learn' ( $\alpha=0.67, M=4.47, S D=0.91$ ).

Social dominance orientation ( $S D O$ ) A six-item SDO scale (based on Pratto et al. 1994; see Onraet et al. 2014) was administered. A sample item is 'Some people are simply inferior to others' $(\alpha=0.77, M=2.78, S D=1.05)$. 


\section{Emma Onraet et al.}

Threat from asylum seekers This measure consisted of six items (combination of items based on Schweitzer et al. (2005) and self-constructed items). Two items tapped into perceived cultural threat (e.g. 'Asylum seeker intake is undermining Dutch culture', $M=4.12, S D=1.71$ ), two items measured perceived threat to safety (e.g. 'Criminality rates will increase because of the influx of asylum seekers', $M=3.75, S D=1.74$ ) and two items measures perceived economic threat (e.g. 'Allowing asylum seekers to live in our country is a threat for our economy', $M=4.27, S D=1.71$ ). Because these types of threat are strongly correlated ( $r$ s all above 0.79 ), we could not meaningfully distinguish between different types and we decided to use an overall threat indicator based on all six items for the further analyses $(\alpha=0.95, M=4.05, S D=1.61)$.

Perception of asylum seeker as legitimate and economic We probed the extent to which participants thought the current wave of asylum seekers were 'legitimate asylum seekers' or 'economic asylum seekers' by asking them two questions: 'According to you, how many of the current wave of asylum seekers are people on the run from war and violence in their home country?' $(M=4.35, S D=1.41)$ and 'According to you, how many of the current wave of asylum seekers are not facing war and violence, but are people looking for a better (economic) future?' $(M=4.10, S D=1.51)$. Participants had to respond on a seven-point Likert scale $(1=$ none; $7=$ all $)$.

\section{Results}

\section{Differences between Demographic Groups}

We first looked for differences between demographic groups with respect to the dependent variables - that is, the aggregated helping scale, policies (harsh versus mild) and welcoming attitudes toward legitimate and economic refugees. The sexes did not differ significantly for any of these variables $(t(991)<|1.67|, p>$ $0.09)$, nor did income yield any significant relationship $(r<|0.05|, p>0.18)$.

Age also bore out a rather modest relationship with the dependent variables. Age was non-significantly related to the helping scale $(r=-0.06$, $p>0.07)$, but it was positively related to harsher policy measurers $(r=0.10$, $p<0.001)$. Moreover, age bore out a significant and negative relationship with a welcoming attitude towards economic asylum seekers $(r=-0.08$, $p<0.05)$, whereas this relationship was non-significant for legitimate asylum seekers $(r=-0.06, p>0.07)$.

Finally, education was significantly related to all dependent variables. Participants who had no formal education $(M=0.45)$ or had completed professional high school $(M=0.45)$ were less likely to (want to) help than those who had completed general high school $(M=0.83)$ or higher education $(M=1.40)\left(F(3,989)=17.75, p<0.001, \mathrm{p}^{2}=0.05\right)$. Education yielded a significant effect on the policy measure $\left(F(3,989)=26.03, p<0.001, \mathrm{p}^{2}=0.07\right)$, with more support for harsher policies among the low-educated $(M=4.22$ 
and 4.34 for the participants with no formal education and a professional degree, respectively) than among the highly educated $(M=3.92$ and 3.50 for the participants who had obtained a high-school degree in general education and those who followed higher education, respectively).

Education had also a small effect on the welcoming attitudes towards economic asylum seekers $\left(F(3,989)=3.53, p<0.02, \mathrm{\eta}^{2}=0.01\right)(M=3.12$, $2.57,2.64$ and 2.88 for the no-formal-education, professional-education, general-education and higher-education groups, respectively). Education did have a larger effect on the welcoming attitudes towards legitimate asylum seekers $\left(F(3,989)=28.47, p<0.001 \mathrm{p}^{2}=0.08\right)(M=4.41,4.37,4.89$ and 5.28 for the no-formal-education, professional-education, general-education and highereducation groups, respectively).

\section{Correlational Analyses}

Table 1 shows that all reactions towards asylum seekers are interrelated. We also notice that RWA and SDO are significantly related to more experienced threat from asylum seekers, perception of asylum seekers as economic and less legitimate, less-helping behaviour, more support for harsh policies and less-welcoming attitudes towards both legitimate and economic asylum seekers.

\section{Table 1}

\section{Correlations among Study Variables}

\begin{tabular}{|c|c|c|c|c|c|c|c|c|c|}
\hline Measure & & 1 & 2 & 3 & 4 & 5 & 6 & 7 & 8 \\
\hline 1 & RWA & - & & & & & & & \\
\hline 2 & $\mathrm{SDO}$ & 0.24 & - & & & & & & \\
\hline 3 & $\begin{array}{l}\text { Perception as } \\
\text { legitimate } \\
\text { asylum seekers }\end{array}$ & -0.21 & -0.39 & - & & & & & \\
\hline 4 & $\begin{array}{l}\text { Perception as } \\
\text { economic } \\
\text { asylum seekers }\end{array}$ & 0.26 & 0.39 & -0.59 & - & & & & \\
\hline 5 & Threat & 0.41 & 0.54 & -0.55 & 0.62 & - & & & \\
\hline 6 & $\begin{array}{l}\text { Welcoming of } \\
\text { legitimate } \\
\text { asylum seekers }\end{array}$ & -0.31 & -0.54 & 0.47 & -0.49 & -0.63 & - & & \\
\hline 7 & $\begin{array}{l}\text { Welcoming of } \\
\text { economic } \\
\text { asylum seekers }\end{array}$ & -0.29 & -0.21 & 0.37 & -0.30 & -0.44 & 0.32 & - & \\
\hline 8 & $\begin{array}{l}\text { Support for harsh } \\
\text { policies }\end{array}$ & 0.41 & 0.51 & -0.58 & 0.58 & 0.77 & -0.64 & -0.47 & - \\
\hline 9 & $\begin{array}{l}\text { Helping } \\
\text { behaviours }\end{array}$ & -0.26 & -0.34 & 0.39 & -0.37 & -0.46 & 0.45 & 0.26 & -0.46 \\
\hline
\end{tabular}

All correlations are significant at $p<0.001$. 


\section{Emma Onraet et al.}

\section{Test of the Integrative Model}

Finally, we wanted to test our Hypothesis concerning the serial mediation processes among our key variables. More specifically, we tested whether right-wing attitudes relate to perceptions of asylum seekers as legitimate and economic, and whether these perceptions further relate to reactions towards asylum seekers over the perception of threat. To do so, we employed

\section{Table 2}

Standardized Estimates of the Serial Mediation Models Testing the Associations of RWA and SDO with Each Outcome, via Perceptions of Legitimate/Economic Asylum Seekers and/or Threat Feelings (Controlling for Age and Education)

\begin{tabular}{|c|c|c|c|c|c|}
\hline & Threat & $\begin{array}{l}\text { Welcoming } \\
\text { of } \\
\text { legitimate } \\
\text { asylum } \\
\text { seekers }\end{array}$ & $\begin{array}{l}\text { Welcoming } \\
\text { of } \\
\text { economic } \\
\text { asylum } \\
\text { seekers }\end{array}$ & $\begin{array}{l}\text { Support } \\
\text { for } \\
\text { harsh } \\
\text { policies }\end{array}$ & $\begin{array}{l}\text { Helping } \\
\text { behaviours }\end{array}$ \\
\hline \multicolumn{6}{|l|}{ From RWA } \\
\hline Total effect & $0.28^{* * *}$ & $-0.17^{* * *}$ & $-0.25^{* * *}$ & $0.27^{* * *}$ & $-0.17^{* * *}$ \\
\hline Direct effect & $0.21^{* * *}$ & $-0.05^{*}$ & $-0.13^{* * *}$ & $0.11^{* *}$ & $-0.08^{*}$ \\
\hline Total indirect effect & $0.07^{* *}$ & $-0.13^{* * *}$ & $-0.11^{* *}$ & $0.16^{* * *}$ & $-0.10^{* *}$ \\
\hline $\begin{array}{l}\text { Indirect effect via legitimate } \\
\text { perceptions }\end{array}$ & & $-0.02^{* * *}$ & $-0.03^{* * *}$ & $0.03^{* * *}$ & $-0.03^{* * *}$ \\
\hline Legitimate perceptions & & $-0.01^{*}$ & $-0.02^{* *}$ & $0.02^{* * *}$ & $-0.02^{* * *}$ \\
\hline Legitimate perceptions-threat & & $-0.01^{* *}$ & $-0.01^{* *}$ & $0.01^{* *}$ & $-0.01^{* *}$ \\
\hline $\begin{array}{l}\text { Indirect effect via economic } \\
\text { perceptions }\end{array}$ & & $-0.04^{* * *}$ & $-0.01^{* * *}$ & $0.04^{* * *}$ & $-0.03^{* * *}$ \\
\hline Economic perceptions & & $-0.02^{*}$ & 0.00 & $0.02^{* *}$ & -0.01 \\
\hline Economic perceptions-threat & & $-0.02^{* * *}$ & $-0.02^{* * *}$ & $0.02^{* * *}$ & $-0.01^{* * *}$ \\
\hline Indirect effect via threat & & $-0.07^{* * *}$ & $-0.07^{* * *}$ & $0.09^{* * *}$ & $-0.05^{* * *}$ \\
\hline \multicolumn{6}{|l|}{ From SDO } \\
\hline Total effect & $0.46^{* * * *}$ & $-0.49^{* * *}$ & $-0.16^{* * *}$ & $0.44^{* * *}$ & $-0.29^{* * *}$ \\
\hline Direct effect & $0.29^{* * *}$ & $-0.27^{* * *}$ & $0.07^{*}$ & $0.10^{* *}$ & $-0.10^{* *}$ \\
\hline Total indirect effect & $0.17^{* * *}$ & $-0.23^{* * *}$ & $-0.22^{* * *}$ & $0.31^{* * *}$ & $-0.21^{* * *}$ \\
\hline $\begin{array}{l}\text { Indirect effect via legitimate } \\
\text { perceptions }\end{array}$ & & $-0.06^{* * *}$ & $-0.09^{* * *}$ & $0.08^{* * *}$ & $-0.08^{* * *}$ \\
\hline Legitimate perceptions & & $-0.04^{* *}$ & $-0.07^{* * *}$ & $0.05^{* * *}$ & $-0.06^{* * *}$ \\
\hline Legitimate perceptions-threat & & $-0.02^{* * *}$ & $-0.02^{* * *}$ & $0.03^{* * *}$ & $-0.02^{* * *}$ \\
\hline $\begin{array}{l}\text { Indirect effect via economic } \\
\text { perceptions }\end{array}$ & & $-0.07^{* * *}$ & $-0.03^{* *}$ & $0.08^{* * *}$ & $-0.06^{* * *}$ \\
\hline Economic perceptions & & $-0.03^{* *}$ & 0.01 & $0.03^{* * *}$ & $-0.03^{*}$ \\
\hline Economic perceptions-threat & & $-0.04^{* * *}$ & $-0.04^{* * *}$ & $0.05^{* * *}$ & $-0.03^{* * *}$ \\
\hline Indirect effect via threat & & $-0.10^{* * *}$ & $-0.10^{* * *}$ & $0.12^{* * *}$ & $-0.08^{* * *}$ \\
\hline
\end{tabular}

Note: ${ }^{*} p<0.05 ;{ }^{* *} p<0.01 ;{ }^{* * *} p<0.001$. 


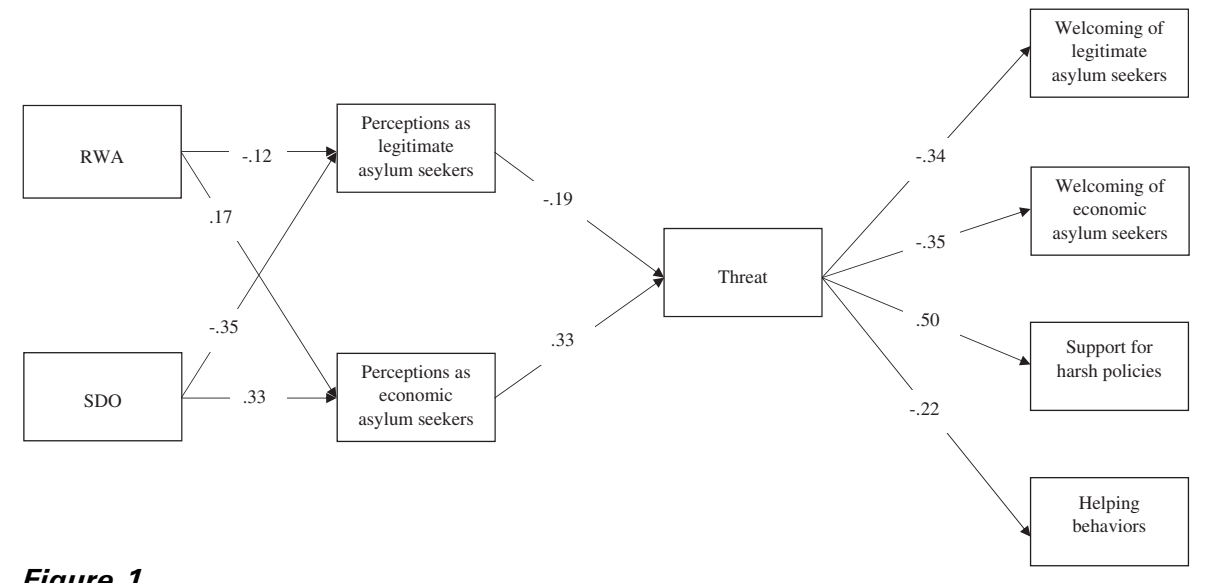

Figure 1

Tested Path Model with Standardized Estimates All estimates are significant at $p<0.001$ and based on a model controlling for age and education. Only direct paths are presented in this figure for reasons of clarity. The estimates for all other paths are available upon request from the authors.

path analyses with maximum-likelihood estimation using the MPlus package (version 7.1; Muthén and Muthén 1998-2012). Standard errors were computed using bootstrapping ( $N=50,000$ bootstrap samples).

An overview of the total, direct and indirect effects of RWA and SDO on each outcome is portrayed in Table 2. Almost all total, direct and total indirect effects were significant. The theoretical model is shown in Figure 1. Overall, we find evidence for our Hypothesis which holds that perceptions of asylum seekers as legitimate and economic and feelings of threat mediate the relationship between right-wing attitudes and reactions towards asylum seekers. More specifically, RWA and SDO are related to higher perceptions of asylum seekers as economic asylum seekers and lower perceptions of asylum seekers as being legitimate. Moreover, perceptions of legitimate asylum seekers relate to more welcoming reactions, more helping behaviour and less support for harsh policies, through lower perceptions of threat. Perceptions of asylum seekers as people with economic motives, on the other hand, lead to increased feelings of threat and ultimately to less-welcoming reactions, lesshelping behaviours and stronger support for harsh policies.

\section{Discussion}

In the present study, we examined reactions of Dutch citizens towards asylum seekers in the midst of the European 'refugee crisis'. Our first aim was to examine how (un)welcoming these reactions were, looking at behavioural and attitudinal reactions as well as support for policies related to asylum seekers. Our second aim was to examine the relationships of RWA and SDO with increased negative and decreased positive attitudes and behaviours towards 
asylum seekers, as well as the mediating processes of (i) increased perception of asylum seekers as mainly driven by economic reasons and decreased perception of asylum seekers as legitimate and (ii) increased feelings of threat.

\section{Reactions to Asylum Seekers}

With respect to our first research aim, it was revealed that most people did not and were not planning to do anything to help asylum seekers. Those who indicated that they already did or were willing to do anything to help the asylum seekers indicated to be willing to do more trivial things such as donating food and money or signing a petition, whereas only a few of them were willing to show more demanding helping behaviours such as welcoming an asylum seeker into their home or participating in a march. Concerning policy support, we noticed that respondents were on average more in favour of harsh policies related to asylum seekers entering the European Union, but reacted more mildly to policies regarding the treatment of asylum seekers once they entered the country.

Respondents were generally more welcoming towards asylum seekers who come to the Netherlands because they face war and violence in their home country (legitimate asylum seekers) compared to asylum seekers who are motivated to provide a better economic future for themselves and their families (economic asylum seekers). Most respondents ( 88 per cent) expressed unwelcoming attitudes towards economic asylum seekers and more than onefifth of the respondents scored at the very unwelcoming extreme of the scale.

Finally, with respect to the demographic variables, it was revealed that sex, age and income bore out negligible relationships with the target variables. The only consistent effects were noted for education. Specifically, the more highly educated were typically more willing to help asylum seekers and more supportive of lenient policies than the lower-educated. Such a substantial difference was also obtained for the welcoming attitude toward legitimate asylum seekers, whereas the difference for the welcoming attitude toward economic refugee seekers was curbed but still significant. These findings echo previous studies that reported among the higher-educated more tolerance and inclusionary attitudes towards ethnic minorities and immigrants (e.g. McLaren 2001; Coenders and Scheepers 2003; Meeusen et al. 2013).

In sum, the present results do not show clear evidence for overall strong welcoming or unwelcoming reactions to asylum seekers. Rather, public reactions towards asylum seeker seem more complex; reactions are very much divided and dependent on the type of helping behaviour, content of the policy measure and perceived 'type' of asylum seekers.

\section{The Role of Right-wing Ideological Attitudes in Explaining Reactions towards Asylum Seekers}

Our second research aim pertained to the impact of right-wing ideological attitudes and, more specifically, RWA and SDO in explaining reactions 
towards asylum seekers. Several interesting findings emerged from our data. First, we found that RWA and SDO uniquely and significantly contributed to the explained variance in the target variables. Both RWA and SDO were related to less-helping behaviour, more support for harsh policies and less-welcoming attitudes towards both legitimate and economic asylum seekers (as stated in Hypothesis 1). These results align well with previous studies which showed that RWA and SDO were unique predictors of political-party preferences and ethnic prejudice (e.g. Van Hiel et al. Duriez 2004; Cornelis and Van Hiel 2015; Van Assche et al. 2019). Second, overall, our data showed that the perception of the presence of different types of asylum seekers and the accompanying perceived level of threat underlie the relationship between right-wing ideological attitudes and reactions towards asylum seekers (as stated in Hypotheses (2) and (4); see also Louis et al. 2007). More specifically, individuals with right-wing attitudes are more likely to perceive the influx of asylum seekers as consisting of economic asylum seekers and less as legitimate asylum seekers compared to individuals with lower right-wing attitudes. This differentiated perception is associated with feelings of threat, and ultimately less-helping behaviour, increased support for harsh policies and lesswelcoming attitudes towards both legitimate and economic asylum seekers. Our study corroborates Hercowitz et al. (2017), who showed that non-genuine asylum seekers tend to be perceived as more threatening, resulting in more exclusionary attitudes towards this group. Although perceptions of threat are considered to be a key factor in explaining attitudes towards asylum seekers (Esses et al. 2017), asylum seekers may provoke a range of other emotional and cognitive reactions as well, such as empathy, guilt, anger, scepticism, fairness concerns, ethical concerns and even disgust. Verkuyten (2004), for example, showed that legitimate asylum seekers elicit feelings of sympathy, whereas economic asylum seekers make people angry, which in turn affects policy support. Unfortunately, we did not measure similar emotional reactions in our study, but it is certainly interesting for future research to test whether sympathy and anger, or related variables such as perspective taking, resentment or perceptions of immorality, unfairness or deception, play a role in explaining why right-wing adherents react more negatively asylum seekers.

Our study is the first to show that ideologically right-wing- and left-wingminded individuals have different perceptions of the motivations of asylum seekers. Right-wing adherents perceive them more as 'fortune seekers' who take advantage of the influx of 'real refugees' to settle in economically more prosperous countries. Left-wing-minded individuals, on the other hand, believe more in the legitimacy of asylum seekers, perceiving them as individuals who have no choice but to flee because they face life-threatening events in their home country. Whereas the distinction between legitimate and economic asylum seekers is often made in public debates, the 'refugee crisis' is a complex phenomenon and can be examined from many other angles as well. Asylum seekers can also be categorized into different groups, resulting in different welcoming attitudes. For example, the study of Bansak et al. 


\section{Emma Onraet et al.}

(2016) also showed that Europeans are more likely to accept asylum seekers who are high-skilled (vs. low-skilled or previously unemployed), young (vs. close to retirement age), have experienced torture (vs. have no special vulnerabilities) and are Christians (vs. Muslims). Especially the last distinction, based on the religious affiliation of the asylum seekers, might be especially relevant in explaining the effects of right-wing attitudes (see Anderson and Antalíková 2014). Right-wing adherents are more likely to perceive cultural and terroristic threats (Onraet et al. 2013), which are often linked to Muslims (Verkuyten and Zaremba 2005; Velasco González et al. 2008). Cowling and Anderson (2019) have shown that prejudice towards asylum seekers is more elevated when they do not share the same religion (e.g. Muslim asylum seekers in a Christian country). It would thus be interesting for future research to uncover whether perceiving asylum seekers as Muslims (vs. nonMuslims) also plays a role in explaining the relationship between right-wing attitudes and reactions towards asylum seekers.

\section{Practical Implications}

Our findings also have implications for how asylum seekers are framed in the media and by politicians. It should come as no surprise that opinions and reactions of the public on migration are influenced by how migration is covered in the media and in the rhetoric of politicians (Esses et al. 2017). Given that there are no objective numbers and hence considerable uncertainty about the actual amount of legitimate versus economic asylum seekers, people often rely on these sources for information as a basis for their judgements. Media and politicians should be aware that framing asylum seekers as economic asylum seekers or using related terms such as 'fortune seekers' may impact upon perceptions of threat and negative reactions toward asylum seekers in the community (see also Verkuyten 2004). This use of language may strengthen existing negative reactions among right-wing adherents or decrease initial more welcoming attitudes among left-wing adherents. Framing asylum seekers as people who are on the run for war and violence, on the other hand, may offer the possibly for more favourable attitudes.

It is also important to note that the resulting evaluative reactions and attitudes are only one outcome variable. The perception of asylum seekers also has an effect on people's behavioural intentions and behaviours as well as on their support of certain policies. The present contribution adds to the small but growing literature that shows that sources of prejudice such as right-wing attitudes and emotional reactions have relevance for the acceptance and support of government policies as well (see Hartley and Pedersen 2015; Hartley et al. 2019).

\section{Limitations}

Although we have collected data in a large heterogeneous sample of Dutch citizens, two questions concerning generalizability of the results arise here. 
First, a limitation of our study is that our sample only consisted of native inhabitants (i.e. participant and both parents born in the Netherlands). Hence, we were unable to examine how citizens with a migration background react towards asylum seekers. Unfortunately, we are not aware of any other study examining reactions of these group. It could be that this group of citizens are more sympathetic and have more positive attitudes towards newcomers compared to natives, because they might have similar experiences to those of refugees or economic migrants, or they may have been told stories by their parents and/or grandparents with first-hand testimonies. On the other hand, newcomers might be threatening to citizens with a migration background as well, especially among those with lower levels of income and education, because asylum seekers pose a direct source of competition for low-status jobs and affordable housing. Group identification may also play a role in welcoming attitudes towards asylum seekers among citizens with a migration background. Verkuyten (2007) showed that Turkish-Dutch Muslims with a strong religious in-group identification show strong positive feelings towards other Muslims. Because the present wave of asylum seekers includes many Muslims, those citizens with high Muslim identification may be more welcoming towards asylum seekers compared to Muslim citizens with lower Muslim identification.

Second, we collected our data in November 2015, amidst the 'refugee crisis', at a time when asylum seekers were subject of a fierce public debate. This raises the question of whether our results capture a specific moment in time or whether our findings are generalizable to today. Since 2015, the influx of asylum seekers in Europe has decreased but is still ongoing (Eurostat 2018). On the one hand, media attention for this topic has dropped significantly and the public debate on asylum seekers is less omnipresent compared to 2015. On the other hand, both minor and major criminal events in Europe have occurred that have been linked to asylum seekers (e.g. the sexual assaults at New Year's Eve 2015-16 in Cologne and the attacks at the Berlin and Strasbourg Christmas markets in December 2016 and 2018), which has had an impact on public opinion as well. Moreover, our study was conducted only a few weeks after the publication of the photograph of five-year-old Syrian boy Aylan Kurdi lying dead on a beach, which might have impacted our results as well. A study by Slovic et al. (2017) found that, after the publication of this picture, people showed an increased interest in asylum seekers and the war in Syria, and donated more money to helping organizations. Hence, it is possible that, in this particular context, the participants in our study were more positive about migration and asylum seekers at that time compared to a few months later of before.

1. Retrieved from https://www.vluchtelingenwerk.nl/sites/default/files/Vluchtelingen werk/Cijfers/20190722_vwn_vluchtelingen-in-getallen.pdf.

2. The data used in the present study was part of a larger data collection including other variables as well. Part of this larger data collection was also used in Study 1 


\section{Emma Onraet et al.}

of Van Assche et al. (2018) and in Study 2 of Van Assche et al. (2018). Only the measure of RWA overlaps between these studies and the present study.

ALTEMEYER, B. (1981) Right-Wing Authoritarianism. Winnipeg: University of Manitoba Press. ALTEMEYER, B. (1998) 'The Other "Authoritarian Personality". Advances in Experimental Social Psychology 30: 47-92.

ANDERSON, J. R. (2018a) 'Implicit and Explicit Attitudes toward Asylum Seekers: Demographic and Ideological Correlates'. Australian Psychologist 53(2): 181-191.

ANDERSON, J. R. (2018b) 'The Prejudice Against Asylum Seekers Scale: Presenting the Psychometric Properties of a New Measure of Classic and Conditional Attitudes'. The Journal of Social Psychology 158(6): 694-710.

ANDERSON, J. R. and ANTALíKOVÁ, R. (2014) 'Framing (Implicitly) Matters: The Role of Religion in Attitudes Toward Immigrants and Muslims in Denmark'. Scandinavian Journal of Psychology 55(6): 593-600.

ANDERSON, J. R. and FERGUSON, R. (2018) 'Demographic and Ideological Correlates of Negative Attitudes towards Asylum Seekers: A Meta-analytic Review'. Australian Journal of Psychology 70(1): 18-29.

ANDERSON, J. R., STUART, A. and ROSSEN, I. (2015) 'Not All Negative: Macro Justice Principles Predict Positive Attitudes towards Asylum Seekers in Australia'. Australian Journal of Psychology 67(4): 207-213.

BANSAK, K., HAINMUELLER, J. and HANGARTNER, D. (2016) 'How Economic, Humanitarian, and Religious Concerns Shape European Attitudes toward Asylum Seekers'. Science 354(6309): 217-222.

CANETTI, D., SNIDER, K. L., PEDERSEN, A. and HALL, B. J. (2016) 'Threatened or Threatening? How Ideology Shapes Asylum Seekers' Immigration Policy Attitudes in Israel and Australia'. Journal of Refugee Studies 29(4): 583-606.

COENDERS, M. and SCHEEPERS, P. (2003) 'The Effect of Education on Nationalism and Ethnic Exclusionism: An International Comparison'. Political Psychology 24(2): 313-343.

CORNELIS, I. and Van HIEL, A. (2015) 'Extreme Right Voting in Western Europe: The Role of Social-cultural and Anti-egalitarianism Attitudes'. Political Psychology 36(6): 749-768.

COWLING, M. M. and ANDERSON, J. R. (2019) 'The Role of Christianity and Islam in Explaining Prejudice against Asylum Seekers: Evidence for Malaysia'. The International Journal for the Psychology of Religion 29(2): 108-127.

COWLING, M. M., ANDERSON, J. R. and FERGUSON, R. (2019) 'Prejudice-relevant Correlates of Attitudes towards Refugees: A Meta-analysis'. Journal of Refugee Studies, 32(3): 502-524.

DUCKITT, J. (2001) 'A Dual-process Cognitive-motivational Theory of Ideology and Prejudice'. Advances in Experimental Social Psychology 33: 41-113.

DUCKITT, J. and SIBLEY, C. G. (2009) 'A Dual Process Model of Ideological Attitudes and System Justification'. In Jost, J., Kay, A. and Thorisdottir, H. (eds) Social and Psychological Bases of Ideology and System Justification. New York: Oxford University Press, pp. 292-313.

EDWARDS, A. (2016) 'Global Forced Displacement Hits Record High', http://www.unhcr.org/ news/latest/2016/6/5763b65a4/global-forced-displacement-hits-record-high.html.

ESSES, V. M., HAMILTON, L. K. and GAUCHER, D. (2017) 'The Global Refugee Crisis: Empirical Evidence and Policy Implications for Improving Public Attitudes and Facilitating Refugee Resettlement'. Social Issues and Policy Review 11(1): 78-123.

EUROSTAT (2018) 'Asylum and First Time Asylum Applicants by Citizenship, Age and Sex. Annual Aggregated Data (Rounded)', http://ec.europa.eu/eurostat/en/web/products-datasets/-/ MIGR_ASYAPPCTZA (accessed March 2018).

EYSENCK, H. J. (1954) The Psychology of Politics. London: Routledge \& Kegan Paul. 
GEORGIOU, M. and ZABOROWSKI, R. (2017) Media Coverage of the 'Refugee Crisis': A Cross-European Perspective. Council of Europe Report DG1 (2017)03, https://rm.coe.int/ 1680706b00 (accessed March 2019).

GOLEC DE ZAVALA, A., CISLAK, A. and WESOlOWSKA, E. (2010) 'Political Conservatism, Need for Cognitive Closure and Intergroup Hostility'. Political Psychology 31(4): 521-541.

HARTLEY, L. K. and PEDERSEN, A. (2015) 'Asylum Seekers and Resettled Refugees in Australia: Predicting Social Policy Attitude from Prejudice versus Emotion'. Journal of Social and Political Psychology 3(1): 142-160.

hARTLEy, L. K., ANDERSON, J. R. and PEDERSEN, A. (2019) 'Process in the Community, Detain Offshore or "Turn Back to the Boats?" Predicting Australian Asylum-seeker Policy Support from False Beliefs, Prejudice and Political Ideology'. Journal of Refugee Studies, 32(4): 562-582.

HERCOWITZ-AMIR, A., RAIJMAN, R. and DAVIDOV, E. (2017) 'Host or Hostile? Attitudes towards Asylum Seekers in Israel and in Denmark'. International Journal of Comparative Sociology 58(5): 416-439.

IPSOS (2016) 'Global Study Shows Many Around the World Uncomfortable with Levels of Immigration', https://www.ipsos.com/ipsos-mori/en-uk/global-study-shows-many-around-world-uncomfortable-levels-immigration (accessed May 2018).

KOC, Y. and ANDERSON, J. R. (2018) 'Social Distance toward Syrian Refugees: The Role of Intergroup Anxiety in Facilitating Positive Relations'. Journal of Social Issues 74(4): 790-811.

KTEILY, N. S., HO, A. K. and SIDANIUS, J. (2012) 'Hierarchy in the Mind: The Predictive Power of Social Dominance Orientation across Social Contexts and Domains'. Journal of Experimental Social Psychology 48(2): 543-549.

LIPSET, S. (1981) Political Man: The Social Basis of politics. Baltimore: The John Hopkins University Press.

LOUIS, W. R., DUCK, J. M., TERRY, D. J., SCHULLER, R. A. and LALONDE, R. N. (2007) 'Why Do Citizens Want to Keep Refugees Out? Threats, Fairness and Hostile Norms In the Treatment of Asylum Seekers'. European Journal of Social Psychology 37(1): 53-73.

LYALL, H. C. and THORSTEINSSON, E. B. (2007) 'Attitudes to the Iraq War and Mandatory Detention of Asylum Seekers: Associations with Authoritarianism, Social Dominance, and Mortality Salience'. Australian Journal of Psychology 59(2): 70-77.

MANCINI, T., BOTTURA, B. and CARICATI, L. (in press) 'The Role of Perception of Threats, Conservative Beliefs and Prejudice on Prosocial Behavioural Intention in Favour of Asylum Seekers in a Sample of Italian Adults'. Current Psychology, doi.org/10.1007/s12144-018-9909-4.

MCLAREN, L. M. (2001) 'Immigration and the New Politics of Inclusion and Exclusion in the European Union: The Effect of Elites and the EU on Individual-level Opinions Regarding European and Non-European Immigrants'. European Journal of Political Research 39(1): 81108.

MEEUSEN, C., DE VROOME, T. and HOOGHE, M. (2013) 'How Does Education Have an IMPACT on Ethnocentrism? A Structural Equation Analysis of Cognitive, Occupational and Network Mechanisms'. International Journal of Intercultural Relations 37(5): 507-522.

MIDDENDORP, C. (1978) Progressiveness and Conservatism: The Fundamental Dimensions of Ideological Controversy and Their Relationship to Social Class. Den Haag, Paris and New York: Mouton.

MUTHÉN, L. K. and MUTHÉN, B. O. (1998-2012) Mplus User's Guide, 7th edn. Los Angeles, CA: Muthén \& Muthén.

ONRAET, E., DHONT, K. and VAN HIEL, A. (2014) 'The Relationships between Internal and External Threats and Right-wing Attitudes: A Three-wave Longitudinal Study'. Personality and Social Psychology Bulletin 40(6): 712-725.

ONRAET, E., VAN HIEL, A., DHONT, K. and PATTYN, S. (2013) 'Internal and External Threat In Relationship with Right-wing Attitudes'. Journal of Personality 81(3): 233-248.

PEW RESEARCH CENTER (2016) 'Europeans Fear Wave of Refugees Will Mean More Terrorism, Fewer Jobs', http://assets.pewresearch.org/wp-content/uploads/sites/2/2016/ 


\section{Emma Onraet et al.}

07/14095942/Pew-Research-Center-EU-Refugees-and-National-Identity-Report-FINAL-July-11 -2016.pdf (accessed May 2018).

PRATTO, F., SIDANIUS, J., STALlWORTH, L. M. and MALle, B. F. (1994) 'Social Dominance Orientation: A Personality Variable Predicting Social and Political Attitudes'. Journal of Personality and Social Psychology 67(4): 741-763.

RIEK, B. M., MANIA, E. W. and GAERTNER, S. L. (2006) 'Intergroup Threat and Out-group Attitudes: A Meta-analytic Review'. Personality and Social Psychology Review 10(4): 336-353.

SCHWEITZER, R., PERKOULIDIS, S., KROME, S., LUDLOW, C. and RYAN, M. (2005) 'Attitudes towards Refugees: The Dark Side of Prejudice in Australia'. Australian Journal of Psychology 57(3): 170-179.

SIBLEY, C. G. and DUCKITT, J. (2008) 'Personality and Prejudice: A Meta-analysis and Theoretical Review'. Personality and Social Psychology Review 12(3): 248-279.

SIDANIUS, J. and PRATTO, F. (1999) Social Dominance: An Intergroup Theory of Social Hierarchy and Oppression. UK: Cambridge University Press.

SLOVIC, P., VÄSTFJÄLL, D., ERLANDSSON, A. and GREGORY， R. (2017) 'Iconic Photographs and the Ebb and Flow of Empathic Response to Humanitarian Disasters'. Proceedings of the National Academy of Sciences 114(4): 640-644.

STEPHAN, W. G. and STEPHAN, C. W. (2000) 'An Integrated Threat Theory of Prejudice'. In Oskamp, S. (ed.) Reducing Prejudice and Discrimination. Mahwah, NJ: Lawrence Erlbaum Associates, pp. 23-45.

THOMSEN, L., GREEN, E. G. T. and SIDANIUS, J. (2008) 'We Will Hunt Them Down: How Social Dominance Orientation and Right-wing Authoritarianism Fuel Ethnic Persecution of Immigrants In Fundamentally Different Ways'. Journal of Experimental Social Psychology 44(6): 1455-1464.

UNITED NATIONS HIGH COMMISSIONER FOR REFUGEES (2015) Global Report, https://www.unhcr.org/gr15/index.xml (accessed March 2019).

VAN ASSCHE, J., ASBROCK, F., DHONT, K. and ROETS, A. (2018) 'The Diversity Challenge for High and Low Authoritarians: Multilevel and Longitudinal Effects through Intergroup Contact and Threat'. Personality and Social Psychology Bulletin 44(8): 1163-1179.

VAN ASSCHE, J., ASBROCK, F., ROETS, A. and KAUFF, M. (2018) 'Positive Neighborhood Norms Buffer Ethnic Diversity Effects on Neighborhood Dissatisfaction, Perceived Neighborhood Disadvantage, and Moving Intentions'. Personality and Social Psychology Bulletin 44(5): 700-716.

VAN ASSCHE, J., VAN HIEL, A., DHONT, K. and ROETS, A. (2019) 'Broadening the Individual Differences Lens on Party Support and Voting Behavior: Cynicism and Prejudice as Relevant Attitudes Referring to Modern-day Political Alignments'. European Journal of Social Psychology 49(1): 190-199.

VAN HIEL, A., PANDELAERE, M. and DURIEZ, B. (2004) 'The Impact of Need for Closure on Conservative Beliefs and Racism: Differential Mediation by Authoritarian Submission and Authoritarian Dominance'. Personality and Social Psychology Bulletin 30(7): 824-837.

VELASCO GONZÁLEZ, K., VERKUYTEN, M., WEESIE, J. and POPPE, E. (2008) 'Prejudice Towards Muslims in the Netherlands: Testing Integrated Threat Theory'. British Journal of Social Psychology 47(4): 667-685.

VERKUYTEN, M. (2004) 'Emotional Reactions to and Support for Immigrant Policies: Attributed Responsibilities to Categories of Asylum Seekers'. Social Justice Research 17(3): 293-314.

VERKUYTEN, M. (2007) 'Religious Group Identification and Inter-religious Relations: A Study among Turkish-Dutch Muslims'. Group Processes \& Intergroup Relations 10: 341-357.

VERKUYTEN, M. (2018) 'The Benefits of Studying Immigration for Social Psychology'. European Journal of Social Psychology 48(3): 225-239.

VERKUYTEN, M. and ZAREMBA, K. (2005) 'Inter-ethnic Relations in a Changing Political Context'. Social Psychology Quarterly 68(4): 375-386. 